\title{
ANALISIS PENERAPAN PRINSIP 5C UNTUK MEMINIMALISIR KREDIT MACET PADA PT. MANDALA MULTIFINANCE Tbk, CABANG MARTAPURA
}

\author{
Ayu Irma Fakhrinie \\ Sekolah Tinggi Ilmu Ekonomi Pancasetia Banjarmasin \\ Jl. Ahmad Yani Km. 5.5 Banjarmasin \\ ayuirma34@gmail.com
}

\begin{abstract}
The purpose of this study was to determine the application of the $5 \mathrm{C}$ principle in granting credit to PT. Mandala Multifinance Tbk, Martapura Branch so far and to find out the application of the 5C principle in granting loans that should be done at PT. Mandala Multifinance Tbk, Martapura Branch so far. Then the application of the $5 \mathrm{C}$ principle in granting credit to PT. Mandala Multifinance Tbk, Martapura Branch that can minimize bad credit and to find out the application of the $5 \mathrm{C}$ principle in granting loans that should be done at PT. Mandala Multifinance Tbk, Martapura Branch that can minimize bad credit.

The method used is qualitative data, qualitative data is realized in describing the explanation in the company. Qualitative data in this study include: bad credit report data for the period 2014 - 2018, data attached to the loan form and the conditions for credit applications. This type of research is a qualitative descriptive analysis

The results showed that in applying the 5C principle in granting credit and to minimize bad credit at PT. Mandala Multifinance Tbk, Martapura Branch is still not effective because in the application of $5 \mathrm{C}$ there are still deficiencies in the analysis conducted for lending.
\end{abstract}

Keywords : 5C Implementation Analysis, Minimizing Bad Debt, PT.MandalaMultifinance Tbk, Martapura Branch.

Abstrak : Tujuan dari penelitian ini untuk mengetahui penerapan prinsip 5C dalam pemberian kredit pada PT. Mandala Multifinance Tbk, Cabang Martapura selama ini dan untuk mengetahui penerapan prinsip 5C dalam pemberian kredit yang seharusnya dilakukan pada PT. Mandala Multifinance Tbk, Cabang Martapura selama ini. Kemudian penerapan prinsip 5C dalam pemberian kredit pada PT. Mandala Multifinance Tbk, Cabang Martapura yang dapat meminimalisir kredit macet dan untuk mengetahui penerapan prinsip 5C dalam pemberian kredit yang seharusnya dilakukan pada PT. Mandala Multifinance Tbk, Cabang Martapura yang dapat meminimalisir kredit macet.

Metode yang digunakan adalah secara data kualitatif, kualitatif adalah data yang diwujudkan dalam menggambarkan penjelasan dalam perusahaan. Data kualitatif pada penelitian ini meliputi : data laporan kredit macet periode 2014 - 2018, data lampiran formulir pemberian kredit dan syarat - syarat untuk pengajuan kredit. Jenis penelitian ini adalah analisa deskriptif kualitatif.

Hasil penelitian menunjukkan bahwa dalam penerapan prinsip 5C dalam pemberian kredit dan untuk meminimalisir kredit macet pada PT. Mandala Multifinance Tbk, Cabang Martapura masih belum efektif dikarenakan dalam penerapan 5C masih terdapat kekurangan dalam analisis yang dilakukan untuk pemberian kredit.

Kata kunci : Analisis Penerapan 5C, Meminimalsir Kredit Macet, PT. Mandala Multifinance Tbk, Cabang Martapura. 


\section{LATAR BELAKANG}

Aktivitas bisnis merupakan fenomena yang sangat kompleks karena mencakup berbagai bidang baik, hukum, ekonomi, dan politik. Dalam kehidupan masyarakat seringkali dapat dilihat bahwa aktivitas manusia dalam dunia bisnis tidak lepas dari peran Leasing selaku pemberi pinjaman bagi masyarakat.

Dalam pembicaraan sehari-hari, Leasing dikenal sebagai lembaga keuangan kegiatan utamanya untuk meminjam uang (kredit) bagi masyarakat yang membutuhkannya. Fungsi utama Leasing adalah sebagai penghimpun dan penyalur dana masyarkat. Dalam menjalankan fungsinya Leasing haruslah berdasarkan demokrasi ekonomi dengan menggunakan prinsip kehati-hatian.

Perkreditan merupakan usaha utama Leasing, tingginya angka kredit yang tersalurkan dari suatu leasing dikarenakan dua alasan, yaitu dilihat dari sisi internal dan eksternal. Dari sisi internal permodalan leasing masih cukup kuat dan portofolio kredit meningkat, sedangkann alasan eksternal leasing adalah membaiknya prospek usaha nasabah.

Dengan semakin meningkatnya penyalur kredit, biasanya disertai pula meningkatnya kredit yang bermasalah atau kredit macet adalah tidak terbayarnya kembali kredit tersebut, baik sebagian maupun seluruhnya. Namun, banyak kejadian-kejadian yan terjadi membuktikan bahwa kredit yang bermasalah atau kredit macet banyak terjadi sebagai akibat pemberian persetujuan kredit yang tidak begitu ketat. Kredit bermasalah atau macet memberikan dampak kurang baik bagi perusahaan, masyarakat dan perbankan indonesia. Likuiditas, keuangan, solvabilitas dan profitabilatas perusahaan sangat dipengaruhi oleh keberhasilan perusahaan dalam mengelola kredit yang disalurkan. Kredit macet atau problem loan adalah kredit yang mengalami pelunasan akibat adanya faktor-faktor atau unsur kesengajaan atau karena kondisi di luar kemampuan debitur. (Siamat, 2013:220). Debitur atau nasabah dalam hal ini adalah sebagai pihak luar yang tidak sedikit dari mereka mengalami kondisi penurunan keuangan, usaha yang dijalankan oleh nasabah tidak stabil atau bisa jadi ada faktor kesengajaan dalam pembayaran tagihan yang tidak tepat waktu. Selain itu terjadinya kredit macet juga dapat disebabkan oleh faktor internal yaitu kelalain dari pihak perusahaan. Dalam hal ini penyebab utama Kredit Macet justru disebabkan oleh kelalaian dari pihak finance itu sendiri. Setiap penyaluran kredit untuk nasabah yang dilakukan oleh finance tentu mengandung resiko, karena manusia sebagai makhluk hidup normal memiliki keterbatasan kemampuan dalam memprediksi masa yang akan datang. Terlebih situasi dan kondisi "lingkungan" yang cepat berubah dan penuh ketidakpastian seperti sekarang ini. Selain kegagalan usaha debitur atau faktur kesengajaan dari debitur seperti disebut diatas, menurunnya kegiatan ekonomi dan tingginya suku bunga kredit juga mempengaruhi kestabilan finance.

Pemberian kredit kepada konsumen atau calon nasabah atau debitur adalah dengan melewati proses pengajuan kredit dan melalui proses analisis pemberian kredit terhadap kredit yang diajukan dalam finance adalah Analisis $5 \mathrm{C}$ (The Five C's of Credit Analysis), yaitu Character (watak), Capacity (kemampuan), Capital (modal), Collateral (jaminan), Condition of Economy (kondisi ekonomi). Finance dapat melakukan analisis permohonan kredit calon debitur apabila persyaratan yang ditetapkan oleh Finance telah terpenuhi. Terhadap kelengkapan data pendukung permohonan kredit, Finance juga melakukan penilaian kelengkapan dan kebenaran informasi dari calon debitur dengan cara petugas Finance melakukan wawancara dan kunjungan (on the spot) ke rumah atau ke tempat usaha dan tempat kerja debitur.

Tujuan dari analisis kredit adalah menilai mutu permintaan kredit yang diajukan oleh calon debitur ataupun permintaan tambahan kredit terhadap kredit yang sudah diberikan yang diajukan 
oleh calon debitur lama. Pengujian kemampuan kesediaan dan kesediaan calon debitur melunasi kredit di pengaruhi faktor internal dan eksternal Finance yang dicakup dalam Analisis 5 C's, sehingga proses analisis dan pelaksanaan Analisis 5 C's ini merupakan tahap yang penting dalam kualifikasi pemberian kredit.

Sebagaimana kita ketahui dampak negatif yang dirasakan oleh nasabah adalah nasabah harus menanggung kewajiban kepada finance. Mengingat setiap pinjaman dari finance memiliki bunga yang cukup memberatkan nasabah, maka jumlah kewajiban nasabah semakin lama akan semakin bertambah besar jika belum dilunasi. Sedangkan dampak negatif yang dialami oleh fianance jauh lebih serius, karena selain dana yang disalurkan untuk kredit berasal dari masyarakat, kredit macet juga mengakibatkan finance kekurangan dana sehingga mempengaruhi kegiatan usaha finance. Dibalik masalah Kredit Macet yang menghantui kedua belah pihak baik dari pandangan sebagai nasabah atau pandangan sebagai finance, tentunya ada cara penyelesaian yang dapat ditempuh oleh keduanya sebagai solusi agar terhindar dari fase terburuk yang bisa saja dialami oleh kedua belah pihak.

Laporan Konsumen Baddebt

Periode Tahun 2014 s/d 2018

\begin{tabular}{|c|c|c|c|c|c|c|}
\hline \multirow{2}{*}{$\begin{array}{c}\text { TA } \\
\mathbf{H U} \\
\mathbf{N}\end{array}$} & \multicolumn{2}{|c|}{ KPM 1} & \multicolumn{2}{|c|}{ KРM 2} & \multicolumn{2}{|c|}{ MOBA } \\
\hline & $\begin{array}{c}\text { Kon } \\
\text { sum } \\
\text { en } \\
\end{array}$ & $\begin{array}{c}\text { Sisa } \\
\text { Pokok }\end{array}$ & $\begin{array}{c}\text { Kon } \\
\text { sum } \\
\text { en }\end{array}$ & $\begin{array}{c}\text { Sisa } \\
\text { Pokok }\end{array}$ & $\begin{array}{c}\text { Kon } \\
\text { sum } \\
\text { en } \\
\end{array}$ & $\begin{array}{c}\text { Sisa } \\
\text { Pokok }\end{array}$ \\
\hline $\begin{array}{c}201 \\
4\end{array}$ & 20 & $\begin{array}{l}\mathrm{Rp} \\
87.826 .5 \\
93\end{array}$ & 19 & $\begin{array}{l}\mathrm{Rp} \\
63.571 . \\
012\end{array}$ & 5 & $\begin{array}{l}\mathrm{Rp} \\
48.457 . \\
966\end{array}$ \\
\hline $\begin{array}{c}201 \\
5 \\
\end{array}$ & 19 & $\begin{array}{l}\text { Rp } \\
58.780 .6 \\
29\end{array}$ & 28 & $\begin{array}{l}\text { Rp } \\
83.730 . \\
734\end{array}$ & 4 & $\begin{array}{l}\mathrm{Rp} \\
32.033 . \\
653 \\
\end{array}$ \\
\hline $\begin{array}{c}201 \\
6\end{array}$ & 23 & $\begin{array}{l}\mathrm{Rp} \\
53.997 .1 \\
21\end{array}$ & 22 & $\begin{array}{l}\mathrm{Rp} \\
70.690 . \\
959\end{array}$ & 2 & $\begin{array}{l}\mathrm{Rp} \\
11.953 . \\
445\end{array}$ \\
\hline $\begin{array}{c}201 \\
7 \\
\end{array}$ & 36 & $\begin{array}{l}\text { Rp } \\
120.121 . \\
629 \\
\end{array}$ & 42 & $\begin{array}{l}\mathrm{Rp} \\
148.25 \\
5.636\end{array}$ & 2 & $\begin{array}{l}\mathrm{Rp} \\
5.094 .5 \\
66 \\
\end{array}$ \\
\hline $\begin{array}{c}201 \\
8\end{array}$ & 29 & $\begin{array}{l}\mathrm{Rp} \\
132.641 . \\
366\end{array}$ & 25 & $\begin{array}{l}\mathrm{Rp} \\
84.010 . \\
873\end{array}$ & 2 & $\begin{array}{l}\mathrm{Rp} \\
37.842 . \\
033\end{array}$ \\
\hline $\begin{array}{l}\text { JU } \\
\mathbf{M L} \\
\mathbf{A H} \\
\end{array}$ & 127 & $\begin{array}{l}\text { Rp } \\
453.367 . \\
338\end{array}$ & 136 & $\begin{array}{l}\text { Rp } \\
450.25 \\
9.214\end{array}$ & 15 & $\begin{array}{l}\text { Rp } \\
135.38 \\
1.663\end{array}$ \\
\hline
\end{tabular}

Sumber : Data diolah penulis

Dari data diatas dapat dilihat pada tahun 2014 kredit macet tertinggi pada KPM1 yaitu 20 konsumen dengan sisa pokok
Rp.87.826.593, pada tahun 2015 kredit macet tertinggi pada KPM2 yaitu 28 konsumen dengan sisa pokok Rp.83.730.734, pada tahun 2016 kredit macet tertinggi pada KPM1 yaitu 23 konsumen dengan sisa pokok Rp.53.997.121, pada tahun 2017 kredit macet tertinggi pada KPM2 yaitu 42 konsumen dengan sisa pokok Rp.148.255.636 dan pada tahun 2018 kredit macet tertinggi yaitu pada KPM1 29 konsumen dengan sisa pokok Rp.132.641.366. Namun kredit macet selama 5 tahun yang paling tertinggi pada KPM2 dengan total 136 konsumen dan sisa pokok Rp.450.259.214.

Maka berdasarkan uraian diatas, penulis ingin meneliti lebih lanjut mengenai permasalahan dan menyusun dalam tesis yang berjudul "Analisis Penerapan Prinsip 5C Untuk Meminimalisir Kredit Macet Pada PT. Mandala Multifinance Tbk, Cabang Martapura".

\section{STUDI LITERATUR}

Menurut teori Ikatan Bankir Indonesia (2014) pembiayaan juga merupakan aktivitas utama bank yang menghasilkan pendapatan bagi bank syariah. Investasi sejumlah dana kepada pihak lain dalam bentuk pembiayaan juga memiliki risiko-risiko seperti gagal bayar dari nasabah pembiayaan. Salah satu prinsip yang sering digunakan dalam evaluasi pembiayaan adalah prinsip 5C, yang digunakan untuk menilai calon nasabah pembiayaan dengan penjelasan sebagai berikut :

\section{Character}

Penilaian karakter calon nasabah pembiayaan dilakukan untuk menyimpulkan bahwa nasabah pembiayaan tersebut jujur, beretika baik, dan tidak akan menyulitkan bank dikemudian hari. Penilaian mengenai karakter sering dilakukan melalui Ikatan Bankir Indonesia (2014 : 203-205).

\section{Capacity}

Penilaian kemampuan calon nasabah pembiayaan dalam bidang usahanya dan atau kemampuan manajemen 
nasabah pembiayaan agar bank yakin bahwa usaha yang akan diberikan pembiayaan tersebut dikelola oleh orang - orang yang tepat.

\section{Capital}

Penilaian atas posisi keuangan calon nasabah pembiayaan secara keseluruhan termasuk aliran kas, baik untuk masalalu atau proyeksi pada masa yang akan datang. Ini dilakukan untuk mengetahui kemampuan permodalan nasabah pembiayaan dalam menjalankan proyek atau usaha nasabah pembiayaan yang bersangkutan.

Condition Of Economy Bank syariah harus melihat kondisi ekonomi yang terjadi di masyarakat secara pesifik melihat adanya keterkaitan dengan jenis usaha yang dilakukan oleh calon penerima pembiayaan. Hal tersebut karena kondisi eksternal berperan besar dalam proses berjalannya usaha calon penerima pembiayaan.

\section{Collateral}

Penilaian atas agunan yang dimiliki calon nasabah pembiayaan. Ini dilakukan untuk mengetahui kecukupan nilai agunan apakah sesuai dengan pemberian pembiayaan.

Menurut Jopie Jusuf Manajemen Bank Syariah akan menerima permohonan dan penerimaan dari calon nasabah untuk melakukan pembiayaan setelah menganalisa permohonan dengan menggunakan prinsip 5C. Ada beberapa faktor resiko yang mempengaruhi penilaian pembiayaan yaitu sebagai berikut

Character (Kepribadian atau Watak)

Capacity (Kemampuan atau
Kesanggupan)
Capital (Modal atau Kekayaan)
Collateral (Jaminan)
Condition Of Economic (Kondisis
Ekonomi)

Hal-hal yang sudah dijelaskan itu harus dilakukan agar berguna untuk mengantisipasi terjadinya pembiayaan bermasalah dikemudian hari.
Character (Kepribadian dan Watak)

Menurut Thamrin Abdullah dan Francis Tantri (2012 : 173) "Character adalah suatu keyakinan bahwa sifat dari orang - orang yang akan diberikan pembiayaan benar-benar dapat dipercaya, hal ini tercermin dari latar belakang nasabah baik latar belakang pekerjaan maupun yang bersifat pribadi seperti cara hidup atau gaya hidup yang dijalaninya, keadaan keluarga, hobi dan lingkungan sosialnya."

Untuk mengetahui character nasabah (calon debitur), ada beberapa hal yang dilakukan oleh Bank, pertama melihat data yang ada di Bank itu sendiri. Hal ini dapat dilakukan apabila pemohon pembiayaan telah ataupun pernah berhubungan baik dengan bak, baik pembiayaan maupun bukan. Disamping itu, Bank juga berusaha mencari informasi ke Bank lain, yaitu Bank yang biasa berhubungan dengan pemohon pembiayaan dan ke Bank Indonesia.

Capacity (Kemampuan dan Kesanggupan)

Menurut pendapat Trisadini P. Usanti Abdul Shomad (2012), Capacity adalah kemampuan nasabah untuk menjalankan usaha berguna untuk memperoleh laba atau keuntungan.

Dalam konsep prinsip 5C dari pembiayaan aspek yang di analisa melalui factor capacity adalah faktor internal perusahaan. Dengan demikian, hasil yang diperoleh dari analisa capacity adalah kekuatan san kelemahan dari suatu perusahaan tersebut.

Capital (Modal atau Kekayaan)

Menurut Prathama, Capital adalah penilaian atas besarnya modal calon nasabah yang diserahkan dalam perusahaan.

Faktor lain yang di analisa oleh Bank adalah aspek modal sendiri (Capital) yang disetor oleh calon debitur kepada bank. Pada bank ini, setiap calon debitur yang ingin melakukan pembiayaan biasanya tidak akan dibiayai sepenuhnya oleh bank. Bank akan melihat terlebih dahulu beberapa capital (modal sendiri) yang dimiliki oleh Calon debitur untuk mengelola usahanya. Setelah bank melihat 
berapa modal sendiri dari calon debitur barulah bank menutupi berapa kekurangan dari modal yang dibutuhkan.

\section{Condition Of Economic (Kondisi Ekonomi)}

Menurut Edi Putra, Condition Of Economic adalah menilai faktor kondisi ekonomi, hendaknya diperhatikan hal-hal yang berkaitan dengan :

Kedudukan usaha calon nasabah dalam bidang usaha sejenis dalam daerah setempat.

Kemungkinan -kemungkinan dari hasil produksinya.

Keadaan ekonomi pada umumnya yang mungkin dapat mempengaruhi usaha calon nasabah.

Menurut Hermansyah, Condition of Economy adalah bahwa dalam pemberian pembiayaan oleh bank, kondisi ekonomi secara umum dan kondisi sektor usaha pemohon pembiayaan perlu memperoleh perhatian dari bank untuk memperkecil resiko yang mungki terjadi diakibatkan oleh kondisi ekonomi tersebut.

\section{Collateral (Jaminan)}

Menurut Edi Putra, collateral yaitu jaminan yang diberikan oleh calon nasabah. Jaminan ini bersifat sebagai jaminan tambahan, kaarena jaminan utama pembiayaan adalah pribadi calon nasabah dan usahanya. Disamping siftanya sebagai tambahan, jaminan juga dapat dikatakan sebagai benteng terakhir bagi keselamatan pembiayaan. Dengan adanya jaminan, bank mendapat kepastian bahwa pembiayaan yang diberikan dapat diterima pasa suatu saat yang telah ditentukan.

Jaminan adalah salah satu persyaratan mutlak dalam pembiayaan. Konsep 5C yang dipakai untuk menganalisa pembiayaan merupakan konsep yang diterima diseluruh dunia dan konsep tersebut menyatakan bahwa jaminan adalah salah satu aspek yang harus dimiliki dalam pembiayaan.

Kata kredit berasal dari bahasa Romawi "credere" yang berarti Percaya (Djumhana, 2013 : 233). Unsur dasar kredit adalah adanya kepercayaan. Pihak yang memebri kredit (Kreditor) percaya bahwa penerima kredit (Debitor) akan sanggup memenuhi segala sesuatu yang telah diperjanjikan, baik menyangkut jangka waktunya, maupun prestasinya dan kontraprestasinya.

Bila kita melihat pendapat para sarjana, tentang definisi dari kredit, ternyata diantara para sarjana, memberi pengertian yang berbeda antara satu sama lain dengan lainnya. Seperti saveberg memberi pengertian, bahwa kredit memiliki arti

Sebagai dasar dari setiap perikatan (Verbintenis) dimana seseorang berhak menuntut sesuatu dari yang lain.

Sebagai jaminan, dimana seseorang menyerahkan sesuatu pada orang lain denga tujuan untuk memperoleh kembali apa yang diserahkan itu (Edy Putra Tje Aman, 2014:01).

Pendapat ini menjurus kepada pengertian kredit pada umumnya, hal ini terlihat dari kata setiap perikatan. Kreditor percaya bahwa Debitor mampu untuk memenuhi perikatan yang disepakati baik perikatan atau uang barang atau keduakeduanya.

JA. Levy (1986) dalam Edy Putra Tje Aman (2014:1) memberi pengertian kredit yaitu menyerahkan secara sukarela sejumlah uang untuk dipergunakan secara bebas oleh penerima kredit. Penerima kredit berhak mempergunakan pinjaman untuk keuntungannya dengan kewajiban mengembalikan jumlah pinjaman itu dibelakang hari. Pendapat tersebut sudah menunjukkan arti yang lebih khusus, bahwa kredit adalah perjanjian pinjam uang.

Definisi kredit dalam berbagai undang - undang selalu mengalami perubahan seperti tercantum dalam Undang - Undang No. 14 Tahun 1967 tentang Perbankan, pada Pasal 1 C disebutkan bahwa kredit yaitu : "Kredit adalah penyediaan uang atau tagihan tagihan yang dapat disamakan dengan itu, berdasarkan persetujuan berkewajiban melunasi hutangnya setelah jangka waktu tertentu, dengan jumlah bunga yang telah ditetapkan (Soedarjanto Imam Syakir, 2013 : 106). 
Dari definisi Undang - Undang No. 14 Tahun 1967 tersebut terkandung beberapa hal yaitu :Perjanjian kredit merupakan perjanjian pinjam uang.

Terjadi dalam dunia perbankan.

Memiliki jangka waktu yang telah ditentukan.

Adanya bunga yang ditetapkan berdasrkan perjanjian.

Selanjutnya Undang - Undang Perbankan tersebut diubah dengan Undang - Undang Nomor 7 Tahun 1992 tenteng Perbankan pada Pasal 1 angka 12, disebutkan bahwa kredit yaitu penyediaan uang atau tagihan yang dapat dipersamakan dengan itu, berdasarkan persetujuan pinjam meminjam antara bank dengan pihak lain yang mewajibkan pihak peminjam untuk melunasi hutangnya setelah jangka waktu tertentu dengan jumlah bunga, imbalan atau pembagian hasil keuntungan (Widjanarto, 2013 : 119).

Definisi kredit menurut UU No. 7 Tahun 1992 nampak lebih lengkap bila dibandingkan dengan definisi yang penulis kemukakan sebelumnya. Dari definisi tersebut terdiri dari beberapa hal penting yaitu :

Perjanjian kredit adalah perjanjian pinjam uang.

Terjadi dalam dunia perbankan.

Untuk jangka waktu tertentu.

Adanya bunga imbalan atau pembagian hasil keuntungan sesuai dengan diperjanjikan.

Kemudian Undang - Undang tersebut telah diuba dengan Undang Undang Nomor 10 Tahun 1998 tentang Perbankan, pada Pasal 1 angka 11 disebutkan bahwa Kredit adalah penyediaan uang atau tagihan yang dipersamakan dengan itu, berdasarkan persetujuan atau kesepakatan pinjam meminjam antara bank dengan pihak yang lain yang mewajibkan pihak peminjam untuk melunasi utangnya setelah jangka waktu tertentu dengan pemberian bunga.

Kredit intisarinya adalah kepercayaan, suatu unsur yang menjadi falsalfah perkreditan dalam arti sebenarnya baik itu meliputi bentuk, macam ragamnya dan asalnya serta kepada siapa pun diberikannya (Adinugroho, 2014:14).

Menurut Ikatan Akuntan Indonesia (2012:No.31) "yang dengan kredit adalah peminjaman uang atau tagihan yang dapat dipersamakan dengan itu berdasarkan atau kesepakatan pinjam meminjam antara bank dengan pihak lain yang mewajibkan pihak peminjam untuk melunasi hutangnya setelah jangka waktu tertentu dengan jumlah bunga, imbalan atau pembagian hasil keuntungan".

Menurut Kuncoro (2012:10), "memberi pengertian Kredit adalah "penyediaan uang atau tagihan atau hak untuk menagih antara kreditur dengan debitur yang dituangkan dalam suatu perjanjian tertulis mengenai jumlah kredit, jangka waktu, bunga dan jaminan kredit”.

Menurut Ismail (2013:93) "kredit merupakan dana dari pihak pemilik dana kepada pihak yang memerlukan dana. Penyaluran dana tersebut didasarkan pada kepercayaan yang diberikan oleh pemilik dana kepada pengguna dana. Sedangkan menurut Undang-Undang Perbankan No.10 tahun 1998, kredit adalah penyedia uang atau tagihan yang berdasarkan persetujuan atau kesepakatan pinjam meminjam antara bank dan pihak lain yang mewajibkan pihak meminjam untuk melunasi utangnya setelah jangka waktu tertentu dengan pemberian bunga".

Rohmatan, 2015. ANALISIS IMPLEMENTASI PRINSIP 5C DALAM UPAYA PENCEGAHAN PEMBIAYAAN MUDHARABAH BERMASALAH DI KSPS BMT BINA UMMAT (BUS) CABANG CEPU. Dengan perkembangan Lembaga Keuangan Syariah baik bank maupun non bank yang sangat baik, terutama Lembaga Keuangan Syariah mikro yaitu BMT (Baitul Mal WatTanwil) haruslah dipertahankan bahakan harus ditingkatkan. Pertumbuhan yang semakin membaik haruslah diimbangi dengan system manajemen resiko yang baik, teruitama pada pemberian pembiayaan, BMT harus berhati-hati dalam memberikan pembiayaan kepada anggota, sebelum memberikan pembiayaan harus memperhatikan prinsip 5C. Permasalahan 
di BMT BUS cabang Cepu mekanisme pembiayaan mudharabah masih kurang tepat dan penerapan prinsip 5C kurang tepat.

Penelitian ini bertujuan untuk mengetahui bagaimana mekanisme pembiayaan Mudharabah dan untuk mengetahui apakah implementasi prinsip 5C sudah diterapkan pada KSP BMT BUS Cabang Cepu dengan baik. Penelitian ini merupakan penelitian kualitatif dengan pendekatan diskriptif. Analisi yang digunakan observasi, wawancara dan dokumentasi. Hal ini penelitian bahwasanya mekanisme pembiayaan mudharabah sama dengan pembiayaan musyarakah dan prinsip 5C sudah diterapkan dengan baik di KSP BMT BUS Cabang Cepu.

Nniek Wahyuni, S.H.,M.Hum, 2018. PENERAPAN PRINSIP 5C DALAM PEMBERIAN KREDIT SEBAGAI PERLINDUNGAN BANK 2016. Pemberian kredit kepada nasabah debitur, dapat menimbulkan kerugian atau risiko bagi bank selaku kreditur apabila hal-hal yang mendasar diabaikan. Untuk memperoleh keyakinandan melindungi kepentingan bank, maka bank harus melakukan penilaian yang seksama terhadap watak, kemampuan, modal, agunan dan prospek usaha dari nasabah debitur, yang dikenal dengan " $5 \mathrm{C}$ ". Namun dalam praktiknya penerapan analisis prinsip 5C ini belum dapat dilaksanakan secara maksimal, bahkan ada kecenderungan bank memberikan kemudahan persyaratan kepada nasabah debitur, karena adanya tuntutan target yang harus dipenuhi bank.

Khomsatun Nafingah, 2018. PENERAPAN PRINSIP 5C PADA PEMBIAYAAN MIKRO IB DALAM MEMINIMALISIR PEMBIAYAAN BERMASALAH DI BRI SYARIAH KCP PURBALINGGA. Dengan demikian dapat dikatakan bahwa analisis pembiayaan dilakukan oleh bank belum efektif. Terbukti dengan adanya pembiayaan bermasalah yang terjadi pada beberapa nasabah pembiayaan iBmikro di BRISyariah KCP Purbalingga. Pembiayaan
mikroiB merupakan pembiayaan yang banyak diminati oleh nasabah. Hal ini dibuktikan dengan banyaknya nasabah dari tahun 2015-2017 sebanyak 784.

Penelitian ini merupakan penelitian deskriftif kualitatif yaitu dengan mendeskripsikan penerapan prinsip 5C pada pembiayaan mikro iiB dalam meminimalisir risiko pembiayaan bermasalah di BRISyariah KCP Purbalingga. Dalam penelitian ini, sumber data yang digunakan adalah data primer dan data sekunder. Kemudian untuk teknik pengumpulan data yang digunakan adalah teknik observasi, wawancara, dan dokumentasi. Selanjutnya berkaitan dengan model analisis data yang digunakan ialah model analisis data yang dikembangkan oleh Miles dan Huberman. Untuk uji keabsahan data dalam penelitian ini menggunakan uji kredibilitas menggunakan metode triangulasih sumber.

\section{Metode Penelitian}

Ditinjau dari jenis datanya rancangan penelitian yang digunakan dalam penelitian ini adalah penelitian kualitatif. Penelitian kualitatif mencerminkan makna kualitatif yang menunjukan segi alamiah yang dipertentangkan dengan kuantum atau jumlah dan atas dasar pertimbangan itulah maka penelitian kualitatif diartikan sebagai penelitian yang tidak mengadakan perhitungan (Moleong, 2015:93).

Adapun jenis pendekatan penelitian ini adalah deskriptif. Penelitian deskriptif yaitu penelitian yang berusaha untuk menuturkan pemecahan masalah yang yang ada sekarnag berdasarkan data-data (Moleong, 2015:98).

Penelitian ini menggunakan metedo (penelitian) deskriptif kualitatif dimana rumusan masalah akan dijawab berdasarkan data yang diperoleh dari berbagai narasumber, baik berupa data primer maupun melalui data sekunder.

Pendekatan yang digunakan adalah pendekatan fenemenologi yang menjelaskan atau mengungkap makna konsep atau fenomena pengalaman yang didasari oleh kesadaran yang terjadi pada beberapa individu. Penelitian ini dilakukan dalam sitiuasi yang alami, sehingga tidak 
ada batasan dalam memaknai atau memahami fenomena yang dikaji.

Berdasarkan masalah yang lebih menekankan pada suatu proses, maka penelitian bermaksud untuk menemukan, memahami, menjelsakan dan memperoleh gambaran yang mendalam tentang Pelaksanaan Analisis Penerapan Prinsip 5C Untuk Meminimalsir Kredit Macet pada PT. Mandala Multifinance Tbk, Cabang Martapura. Pendekatan tersebut digunakan dengan pertimbangan-pertimbangan :

Penelitian kualitatif menyajikan bentuk holistik (menyeluruh) dalam menganalisis suatu fenomena.

Penelitian jenis ini lebih peka menagkap informasi kualitatif diskriptif dengan secara relatif tetap berusaha mempertahankan keutuhan (wholeness) dari objek, artinya bahwa data yang dikumpulkan dalam rangka studi kasus dipelajari secara keseluruhan yang terintegrasi.

Sedangkan menurut Nawawi (2015:9) metode deskriptif dapat diartikan sebagai prosedur pemecahan masalah yang diselidiki dengan menggambarkan / melukiskan keadaan (yang diselidiki dengan menggambarkan / melukiskan keadaan) subjek/objek (seseorang, lembaga, masyarkat dan lain-lain) pada saat sekarang berdasarkan fakta-fakta yang tampak atau sebagaimana adanya.

Definisi Operasional Variabel

Kredit

Kredit adalah penyediaan uang atau tagihan-tagihan yang dapat disamakan dengan itu, berdasarkan persetujuan pinjam meminjam antara finance dengan nasabah. Pihak peminjam berkewajiban melunasi hutangnya setelah jangka waktu tertentu, dengan jumlah bunga yang telah ditetapkan.

Prinsip 5C

Prinsip 5C adalah penilaian mutu permintaan kredit baru yang diajukan oleh calon debitur ataupun permintaan tambahan kredit terhadap kredit yang sudah diberikan yang diajukan oleh calon debitur lama yang dilakukan melalui Prinsip 5C (The Five C's of Credit Analysis), yaitu Character (watak),
Capacity (kemampuan), Capital (modal),

Collateral (jaminan), Condition of

Economy (kondisi ekonomi).

Character (Kepribadian dan Watak)

Menurut Ikatan Bankir Indonesia (2014:203-205) "Character adalah Penilaian karakter calon nasabah yang dilakukan untuk menyimpulkan bahawa nasabah tersebut jujur, beritikad baik, dan tidak akan menyulitkan dikemudian hari." Capacity (Kemampuan dan Kesanggupan)

Menurut pendapat Trisadini P. Usanti Abdul Shomad (2012), Capacity adalah kemampuan nasabah dalam menjalakan keuangan yang ada pada usaha yang dimilikinya. Apakah nasabah tersebut pernah mengalami sebuah permasalahan keuangan sebelumnya atau tidak, dimana prisnsip ini menilai akan kemampuan membayar kredit.

Capital (Modal atau Kekayaan)

Menurut Prathama, Capital terkait kondisi aset dan kekayaan yang dimiliki, khususnya yang mempunyai sebuah usaha. Capital ini dinilai dari laporan tahunan perusahaan yang dikelola nasabah, sehingga dari penilaian, pihak kredit dapat menentukan layak atau tidaknya nasabah tersebut mendapat pinjaman, lalu seberapa besar bantuan kredit yang akan diberikan.

Collateral (Jaminan)

Menurut Edi Putra, collateral yaitu jaminan yang perlu diperhatikan. Prinsip ini perlu diperhatikan bagi nasabah ketika mereka tidak dapat memenuhi layak atau tidaknya jaminan. Ketika mereka tidak dapat memenuhi kewajiban dalam mengembalikan pinjaman pihak kredit. Jika hal demikian terjadi, maka sesuai dengan ketentuan yang ada, pihak bank bisa saja menyita aset yang telah dijanjikan sebelumnya sebagai sebuah jaminan.

Condition of Economic (Kondisi
Ekonomi)

Prinsip ini dipengaruhi oleh faktor luar dari phak kreditur maupun nasabah. Kondisi perekonomian suatu daerah atau negara memang sangat berpengaruh kepada kedua belah pihak, dimana usaha yang dijalankan oleh nasabah sangat tergantung pada kondisi perekonomian baik mikro maupun makro,sedangkan 
pihak kreditur meghadapi permasalahan yang sama. Untuk memperlancar komunikasi antara nasabah dengan kreditur.

Jenis Data dan Sumber Data

Jenis Data

Kualitatif

Data kualitatif adalah data informasi yang berbentuk kalimat verbal bukan berupa symbol angka atau bilangan. Data kualitatif dapat melalui suatu proses menggunakan teknik analisis mendalam dan tidak bisa diperoleh secara lansung.

Dengan kata lain untuk mendapatkan data kualitatif lebih banyak membutuhkan waktu dan sulit dikerjakan karena harus melakukan wawancara, observasi, diskusi atau pengamatan.

Metode penelitian kualitatif adalah sebuah cara atau upaya lebih untuk menekankan pada aspek pemaahaman secara mendalam pada suatu permasalahan. Adapun yang termasuk data kualitatif dalam penelitian yaitu gambaran obyek penelitian, meliputi : sejarah singkat, visi dan misi, struktur PT Mandala Multifinance Tbk, Cabang Martapura.

Kuantitaf

Data kuantitatif adalah data informasi yang berupa simbol bilangan. Berdasarkan simbol-simbol angka tersebut, perhitungan secara kuantitatif dapat dilakukan untuk mrnghasilkan suatu kesimpulan yang berlaku umum didalam suatu parameter.

Nilai data bisa berubah-rubah atau bersifat variartif. Proses pengumpulan dan kuantitatif tidak membutuhkan banyak waktu dan sangat mudah dilakukan.

Penelitian ini bertujuan untuk mengetahui dampak dari kredit macet pada PT Mandala Multifinance Tbk, Cabang Martapura yang dilaksanakan melalui analisis penerapan prinsip 5C Untuk Meminimalisir kredit macet. Adapun yang termasuk data kuantitatif dalam penelitian ini, yaitu : jumlah data kredit pada PT Mandala Multifinance Tbk, Cabang Martapura.

Sumber Data
Sumber data di lihat dari cara memperolehnya terbagi menjadi dua yaitu Data Primer dan Data Sekunder. Untuk itu metode pengumpulan data harus sesuai dengan penelitian yang sedang dilakukan, apakah menggunakan primer atau sekunder.

Data Primer

Menurut kamus Besar Indonesia, data primer adalah data diperoleh seseorang peneliti langsumg dari obyeknya. Sedangkan menurut para Pakar Penelitian Data Primer adalah penelitian yang diperoleh secara langsung dari sumber aslinya baik secara wawancara, jejak pendapat dari individu atau kelompok, maupun hasil observasi dari suatu obyek, kejadian, atau hasil pengujian. Dalam hal ini peneliti mengumpulkan data dengan cara memberikan kuesioner atau dengan cara mengamati obsevarsi .

Menurut wikipedia Indonesia kelebihan dari data primer adalah lebih mencerminkan kebenaran berdasarkan dengan apa yang dilihat dari dan didengar langsung oleh peneliti sehingga unsurunsur kebohongan dari sumber fenomenal dapat dihindari. Keuangan data primer adalah membutuhkan waktu yang relatif lama serta baiya yang dikeluarkan cukup besar.

Data Sekunder

Data sekunder adalah data yang diperoleh seorang peneliti secara tidak langsung dari obyeknya, tetapi melalui sumber lain, baik lisan maupun tulis. Misalnya buku catatan, bukti yang telah ada, atau arsip, baik yang dipublikasikan maupun tidak dipublikasikan secara umum. Dalam hal ini peneliti mengumpulkan data dengan cara berkunjung keperpustakaan, pusat kajian, pusat arsip atau membaca banyak buku yang berhubungan dengan penelitinya.

Kelebihan dari data sekunder adalah waktu dan biaya yang dibutuhkan untuk penelitian untuk mengklarifikasi permasalahan dan mengevaluasi data, relatif lebih sedikit dibandingkan dengan pengumpulan data primer. 
Kekuranganan dari data sekunder adalah jika sumber data terjadi kesalahan, kadaluwarsa atau sudah tidak relevan dapat mempengaruhi hasil.

Data yang digali terbagi dalam dua tingkatan yaitu data utama dan data penunjang. Data utama dalam penelitian ini adalah data dari dua variabel bebas yaitu komunikasi kepemimpinan dan religiusitas, satu variabel terkait yaitu kinerja keuangan PT Mandala Multifinance Tbk, Cabang Martapura sedang data penunjang adalah data yang menyangkut gambaran umum lokasi penelitian.

Populasi dan Sampel

Penelitian ini menggunakan teknik purposive dimana penarikan sampel disesuaikan dengan tujuan penelitian dan didasarkan atas beberapa pertimbangan sebagai berikut :

Merupakan karyawan PT. Mandala Multifinance Tbk, Cabang Martapura dan dari 27 orang karyawan 6 orang menjadi informan.

Mengetahui mengenai prinsip penerapan 5C Untuk Meminimalisir Kredit Macet pada PT. Mandala Multifinance Tbk, Cabang Martapura.

Bekerja minimal 2 (dua) tahun pada PT. Mandala Multifinance Tbk, Cabang Martapura.

Teknik Pengumpulan Data

\section{Wawancara}

Wawancara merupakan teknik pengumpulan data yang dilakukan melalui tanya jawab dengan responden penelitian mengenai analisis penerapan prinsip 5C untuk meminimalisir kredit macet pada PT. Mandala Multifinance Tbk, Cabang Martapura.

\section{Observasi}

Dalam cara ini penulis mengadakan pengamatan dan pecatatan secara langsung terhadap informasi - informasi yang sekiranya dapat dijadikan bahan dalam penelitian.
Dokumentasi adalah teknik pengumpulan data yang dilakukan melalui pengumpulan data atau arsip tertulis khususnya yang berhubungan dengan penelitian yang mengenai PT. Mandala Multifinance Tbk, Cabang Martapura seperti sejarah berdirinya perusahaan, tugas pokok dan fungsi perusahaan, daftar karyawan, serta daftar nasabah yang kreditnya dan bermasalah dan data penjualan perusahaan.

\section{Teknik Analisis Data}

Penelitian ini menggunakan pendekatan penelitian deskriptif dengan analisis kualitatif yang menggunakan variabel prinsip $5 \mathrm{C}$, untuk meminimalisir kredit macet.

Lokasi dan Jadwal Penelitian

Lokasi Penelitian

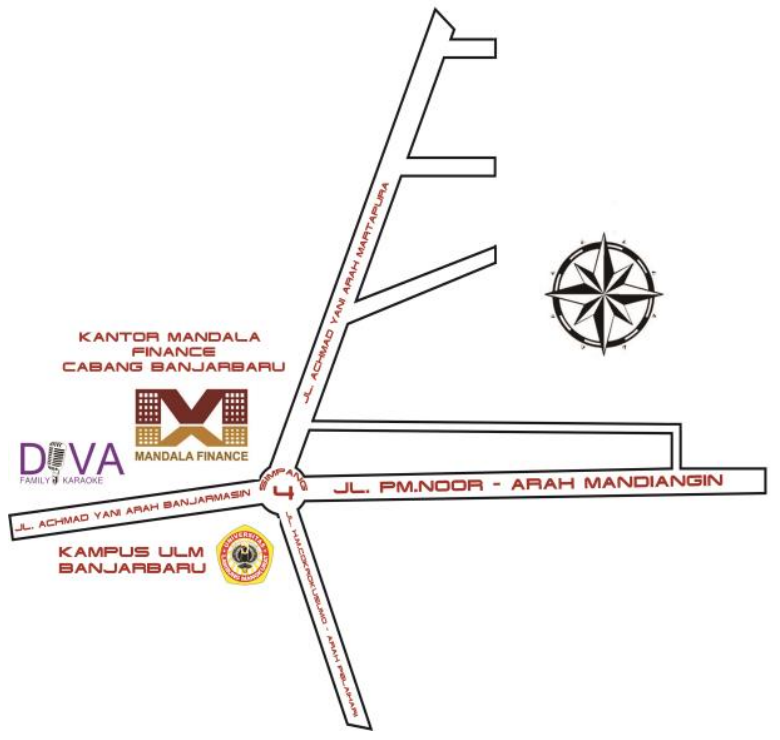

\section{Dokumentasi}




\section{Hasil Penelitian dan Pembahasan}

Data Kredit Bermasalah

Laporan Konsumen Baddebt

Periode Tahun 2014 s/d 2018

\begin{tabular}{|c|c|c|c|c|c|c|}
\hline \multirow{2}{*}{$\begin{array}{l}\text { TAHU } \\
\mathbf{N}\end{array}$} & \multicolumn{2}{|c|}{ KPM 1} & \multicolumn{2}{|c|}{ KPM 2} & \multicolumn{2}{|c|}{ МОВА } \\
\hline & $\begin{array}{c}\text { Konsu } \\
\text { men }\end{array}$ & Sisa Pokok & $\begin{array}{c}\text { Konsu } \\
\text { men }\end{array}$ & Sisa Pokok & $\begin{array}{c}\text { Konsu } \\
\text { men }\end{array}$ & Sisa Pokok \\
\hline 2014 & 20 & $\begin{array}{l}\mathrm{Rp} \\
87.826 .593\end{array}$ & 19 & $\begin{array}{l}\mathrm{Rp} \\
63.571 .012\end{array}$ & 5 & $\begin{array}{l}\mathrm{Rp} \\
48.457 .966\end{array}$ \\
\hline 2015 & 19 & $\begin{array}{l}\mathrm{Rp} \\
58.780 .629 \\
\end{array}$ & 28 & $\begin{array}{l}\mathrm{Rp} \\
83.730 .734 \\
\end{array}$ & 4 & $\begin{array}{l}\mathrm{Rp} \\
32.033 .653\end{array}$ \\
\hline 2016 & 23 & $\begin{array}{l}\mathrm{Rp} \\
53.997 .121\end{array}$ & 22 & $\begin{array}{l}\mathrm{Rp} \\
70.690 .959\end{array}$ & 2 & $\begin{array}{l}\mathrm{Rp} \\
11.953 .445\end{array}$ \\
\hline 2017 & 36 & $\begin{array}{l}\mathrm{Rp} \\
120.121 .629\end{array}$ & 42 & $\begin{array}{l}\mathrm{Rp} \\
148.255 .636\end{array}$ & 2 & $\begin{array}{l}\mathrm{Rp} \\
5.094 .566\end{array}$ \\
\hline 2018 & 29 & $\begin{array}{l}\mathrm{Rp} \\
132.641 .366\end{array}$ & 25 & $\begin{array}{l}\mathrm{Rp} \\
84.010 .873\end{array}$ & 2 & $\begin{array}{l}\mathrm{Rp} \\
37.842 .033\end{array}$ \\
\hline $\begin{array}{c}\text { JUML } \\
\text { AH }\end{array}$ & 127 & $\begin{array}{l}\text { Rp } \\
\text { 453.367.338 }\end{array}$ & 136 & $\begin{array}{l}\mathrm{Rp} \\
\mathbf{4 5 0 . 2 5 9 . 2 1 4}\end{array}$ & 15 & $\begin{array}{l}\text { Rp } \\
135.381 .663\end{array}$ \\
\hline
\end{tabular}

Dari data diatas dapat dilihat pada tahun 2014 kredit macet tertinggi pada KPM1 yaitu 20 konsumen dengan sisa pokok Rp.87.826.593, pada tahun 2015 kredit macet tertinggi pada KPM2 yaitu 28 konsumen dengan sisa pokok Rp.83.730.734, pada tahun 2016 kredit macet tertinggi pada KPM1 yaitu 23 konsumen dengan sisa pokok Rp.53.997.121, pada tahun 2017 kredit macet tertinggi pada KPM2 yaitu 42 konsumen dengan sisa pokok Rp.148.255.636 dan pada tahun 2018 kredit macet tertinggi yaitu pada KPM1 29 konsumen dengan sisa pokok Rp.132.641.366. Namun kredit macet selama 5 tahun yang paling tertinggi pada KPM2 dengan total 136 konsumen dan sisa pokok Rp.450.259.214.

Hasil Wawancara

Penerapan Character (Kepribadian dan Watak)

Penilaian karakter calon nasabah selama ini yang dilakukan dengan cara melakukan kunjungan kerumah saat calon nasabah mengajukan pinjaman, menilai calon nasabah dari sifat pribadi cara hidup atau gaya hidup, keadaan keluarga, calon nasabah dikenal lingkungan tempat tinggal. Penerapan Capacity (Kemampuan dan Kesanggupan)

Penerapan capacity yang dilakukan selama ini dilihat dari pekerjaan dan usaha konsumen dan penghasilannya selama satu bulan, apakah mampu untuk membayar kewajiban, dilihat juga pengeluaran dalam perbulan apakah masih ada sisa untuk membayar kewajiban.

Maka dari itu penghasilan perbulan caalon nasabah dikurang dengan biaya hidup dapat diketahui apakah ada sisa pendapatan untuk membayar kredit pinjaman.

Penerapan Capital (Modal dan Kekayaan)

Penerapan capital selama ini dilihat dari usaha calon nasabah apakah nasabah memperoleh keuntungan dari usaha atau modal yang mereka miliki sehingga dapat dinilai apakah layak atau tidaknya nasabah tersebut mendapat pinjaman, dan dapat ditentukan berapa besar kredit yang akan didapatkan oleh nasabah.

Penerapan Condition Of Economic (Kondisi Ekonomi)

Penerapan ini dipengaruhi oleh faktor di luar dari pihak kreditur dan debitur. Karena dilihat dari kondisi perekonomian suatu daerah atau negara memang sangat berpengaruh kepda kedua belah pihak, dimana usaha yang dijalankan nasabah sangat bergantung pada kondisi perekonomian, dengan itu untuk memperlancar kerjasama dari kedua belah pihak, maka penting adanya untuk memperlancar komunikasi antara nasabah dengan baik.

Penerapan Collateral (Jaminan)

Penerapan collateral selama ini dilihat dari jaminan bpkb yang akan dijaminkan, tetapi jaminan dinilai dari layak atau tidaknya untuk diberikan jaminan. Namun juga perlu diperhatikan bagi para nasabah ketika mereka tidak dapat memenuhi kewajibannya dalam mengembalikan pinjaman, maka sesuai dengan ketentuan yang ada pihak kreditur bisa saja menyita jaminan.

\section{Pembahasan}

Penerapan prinsip 5C dalam pemberian kredit pada PT. Mandala Multifinance Tbk, Cabang Martapura

Character (Kepribadian dan Watak)

Pemberian kredit didasarkan atas kepercayaan, jadi yang mendasari suatu kepercayaan yaitu adanya keyakinan dari pihak kreditur bahwa debitur mempunyai moral, watak ataupun sifat-sifat pribadi 
yang positif ataupun koperatif dan juga mempunyai rasa tanggung jawab, baik dalam kehidupan pribadi sebagai manusia, kehidupan sebagai anggota masyarakat ataupun dalam menjalankan usahanya. Penilaian kredit khsusnya dari aspek character dilihat dari beberapa indikator yaitu :

Sifat atau itikad baik dari debitur merupakan faktor utama dalam pemberian kredit.

Kreditur sebagai penyalur dana harus menerapkan prinsip kehati-hatian. Character merupakan salah satu faktor yang harus diperhatikan sebagai yang paling penting, sebelum memutuskan pemberian kredit yang akan direalisasi, karena mengambarkan moral, watak, ataupun sifat-sifat pribadi yang positif dan mempunyai rasa tanggung jawab baik dalam kehidupannya sebagai anggota masyarakat ataupun dalam tingkat kejujuran untuk memenuhi kewajibankewajibanya.

Berdasarkan hasil obeservasi yang peneliti lakukan, penilaian moral risk yang telah ditetapkan oleh PT. Mandala Multifinance Tbk, Cabang Martapura dimana fungsi penilaian itikad baik calon debitur ini telah mampu menilai kemauan membayar atas pengajuan kredit.

Berdasarkan hasil wawancara dengan karyawan pada PT. Mandala Multifinance Tbk, Cabang Martapura diperoleh informasi bahwa untuk dapat melaksanakan kegiatan penilaian itikad baik dari calon debitur telah ditetapkan beberapa ketentuan penilaian kepada calon debitur dengan adanya wawancara secara langsung dan melihat latar belakang debitur di lingkungan tempat tinggal. Dengan ini kita dapat menilai secara langsung bagaimana watak, sifat bahkan kemauan membayar kembali kreditnya kepada PT. Mandala Multifinance Tbk, Cabang Martapura.

Berdasarkan hasil observasi dan wawancara yang dilakukan peneliti, maka peneliti menganalisis bahwa pelaksanaan analisis pemberian kredit yang sesuai dengan ketentuan yang ada pada PT.Mandala Multifinance Tbk, Cabang
Martapura belum berjalan dengan baik karena dalam penilaian karakter belum diadakan nya BI Checking untuk menganalisa kredit pinjaman nasabah.

Capacity (Kemampuan atau Kesanggupan).

Capacity merupakan salah satu prinsip dalam melaksanakan analisis pemberian kredit, dimana pihak kreditur menilai kemampuan calon debitur untuk melunasi seluruh kewajiban sesuai dengan perjanjian yang telah disepakatinya. PT. Mandala Multifinance Tbk, Cabang Martapura telah melakukan penilaian terhadap kapasitas atau kemampuan calon debitur untuk mengembalikan kreditnya agar proses dapat berjalan dengan lancar.

Kemampuan berhubungan dengan pencarian penghasilan tetap dan tambahan bagi suami istri dan rincian pengeluarannya. Kemampuan seorang calon debitur dalam mengelola keuangannya setiap bulan, dipertimbangkan dengan tingkat kebutuhan yang meningkat dan keadaan ekonomi nasional, akan terlihat kemampuan membayar fasilitas kredit yang akan diberikan kelak.

Kemampuan dari debitur sangat mempengaruhi pengembalian pinjaman kredit. Kegiatan penilaian kemampuan dari calon debitur merupakan tahapan dimana pihak kreditur menilai kemampuan tahap panjang untuk masa yang akan datang seorang calon debitur untuk membayar kewajibannya. Dengan penilaian kemampuan dalam pengembalian kredit dari calon debitur ini diharapkan pihak PT. Mandala Multifinance Tbk, Cabang Martapura dapat memperkecil kemungkinan terjadinya resiko kredit bermasalah.

Analisis yang dilakukan oleh analisis kredit dengan melihat dokumen calon debitur, seperti perincian penghasilan tetap suami istri, pembayaran rekening listrik, air, dan telepon, yang diberikan oleh calon debitur akan dapat diketahui secara pasti tingkat ketertiban pembayarannya.

Berdasarkan hasil observasi yang telah dilakukan oleh peneliti, kegiatan penilaian kemampuan dalam pengembalian 
kredit dari calon debitur dilakukan dengan yang telah ditetapkan oleh PT. Mandala Multifinance Tbk, Cabang Martapura, dimana fungsi penilaian kemampuan calon debitur ini PT. Mandala Multifince Tbk, Cabang Martapura telah mampu menilai kemampuan membayar calon debitur yang mengajukan kreditnya.

Berdasarkan hasil wawancara dengan karyawan kredit pada PT. Mandala Multifinance Tbk, Cabang Martapura diperoleh informasi bahwa untuk dapat melaksanakan kegiatan penilaian kemampuan dalam pengembalian kredit calon debitur yang telah ditetapkan PT. Mandala Multifinance Tbk, Cabang Martapura maka terdapat berapa ketentuan penilaian kemampuan kepada calon debitur dengan adanya bukti langsung berupa slip gaji dari perusahaan tempat calon debitur bekerja atau tempat usaha calon debitur, perhitungan biaya sehari-hari yang dikeluarkan oleh calon debitur dan keluarga apabila telah menikah yang dibuktikan dengan Kartu Keluarga, dan disesuaikan dengan wawancara secara langsung kepada bagian kredit. Dengan metode perhitungan kebutuhan dari calon debitur dapat ditarik kesimpulan apakah calon debitur tersebut mampu memenuhi segala kewajiban akan kreditnya kepada PT. Mandala Multifinance Tbk, Cabang Martapura.

Berdasarkan hasil observasi dan wawancara yang dilakukan peniliti, maka peneliti menganalisa bahwa pelaksanaan analisis pemberian kredit yang sesuai dengan ketentuan yang ada pada PT. Mandala Multifinane Tbk, Cabang Martapura belum berjalan dengan baik karena dalam menilai kemampuan calon nasabah perlu dilakukan bukti penghasilan print out dari rekening bank jika penghasilannya melalui rekening bank dan jika penghasilan diterima langsung perlu minta nomor telepon bagian keuangan tempat calon nasabah bekerja agar kita dapat informasi yang akurat untuk penghasilan calon nasabah.

Capital (Modal atau Kekayaan)

$$
\text { Capital merupakan tahapan }
$$

selanjutnya dari analisis kredit yang menilai seberapa besar kekayaan yang dimiliki oleh calon debitur sebelum mendapatkan kredit dari kreditur. PT. Mandala Multifinance Tbk, Cabang Martapura menilai kekayaan calon debitur sebelum mendapatkan kreditnya karena tanpa bisa dihindari penilaian pemberian kredit akan diberikan pada calon debitur yang mempunyai kekayaan yang lebih banyak dari debitur lain sebagai menghindari terjadinya kredit bermasalah. Hal ini dilakukan pihak kreditur untuk mempelancar proses kredit sendiri. Adapun indikator yang digunakan oleh PT. Mandala Multifinance Tbk, Cabang Martapura dalam menilai kekayaan yang dimiliki oleh calon debitur adalah sebagai berikut :

Modal atau sumber pembiayaan lain yang dimiliki oleh

debitur memiliki pengaruh dalam pemberian kredit

Kegiatan penilaian sumber modal serta pembiayaan lainnya yang dimiliki calon debitur merupakan tahap analisis dimana menilai sumber modal atau penghasilan yang didapat oleh calon debitur yang mengajukan kreditnya. Penilaian sumber modal atau pembiayaan lainnya dari calon debitur ini bertujuan untuk mengurangi terjadinya kredit bermasalah karena dengan menilai dari mana sumber modal serta pembiayaan lainnya yang dimiliki calon debitur maka para analisis kredit dapat mengetahui seberapa setabil kekayaan yang dimilikinya.

Modal merupakan penilaian yang dilakukan analisis kredit serupa analisis kemampuan apabila dalam kredit. Modal yang dimiliki oleh calon debitur diukur dari laporan keuangan calon debitur, laporan keuangan tersebut berisi penghasilan debitur dikurangi biaya hidup perbulan.

Berdasarkan hasil observasi yang telah dilakukan oleh peniliti, kegiatan penilaian sumber modal pembiayaan lainnya yang dimiliki calon debitur yang telah ditetapkan oleh PT. Mandala Multifinance Tbk, Cabang Martapura, dimana dengan fungsi penilaian 
kemampuan modal pembiayaan lainnya calon debitur ini PT. Mandala Multifinance Tbk, Cabang Martapura telah mampu menilai kemampuan membayar dari calon debitur yang mengajukan kreditnya.

Berdasarkan hasil wawancara dengan analisis kredit PT. Mandala Multifinance Tbk, Cabang Martapura diperoleh informasi bahwa untuk dapat melaksanakan kegiatan penilaian sumber modal dan pembiayaannya lainnya yang dimiliki calon debitur yang telah ditetapkan PT. Mandala Multifinance Tbk, Cabang Martapura terdapat beberapa ketentuan penilaian sumber modal dan pembiayaan lainnya yang dimiliki calon debitur dengan menilai cara kerja perusahaan yang menentukan seberapa kuat ketahanan sebuah perusahaan untuk memperkerjakan karyawannya. Dengan metode ini perusahaan pihak PT. Mandala Multifinance Tbk, Cabang Martapura dapat memperhitungkan seberapa aman kredit yang disalurkannya karena jaminan perusahaan tempat calon debitur bekerja ikut menentukan kembalinya kredit yang dipinjamkan secara teratur sesuai dengan perjanjian.

Kepemilikan modal yang dimiliki oleh debitur berpengaruh terhadap pemberian kredit.

Pelaksanaan kegiatan penilaian kepemilikan modal yang dimiliki oleh debitur adalah tahapan yang harus dilakukan oleh para analisis kredit dimana menilai kekayaan seorang calon debitur sebelum mendapatkan kreditnya. Penilaian modal atau kekayaan seorang calon debitur bertujuan untuk mengurangi terjadinya kredit bermasalah karena dengan menilai sejauh mana kekayaan calon debitur itulah para analisis kredit dapat mengetahui ketahanan financial calon debitur.

Berdasarkan hasil observasi yang telah dilakukan oleh peneliti, kegiatan penilaian kepemilikan modal seorang calon debitur yang dilaksanakan yang telah ditetapkan oleh PT. Mandala Multifinance Tbk, Cabang Martapura, dimana dengan fungsi penilaian modal atau kekayaan seorang calon debitur ini PT. Mandala Multifinance Tbk, Cabang Martapura telah mampu menilai ketahanan financial dari calon debitur yang mengajukan kreditnya.

Berdasarkan hasil wawancara dengan analisis kredit diperoleh informasi bahwa untuk dapat melaksanakan kegiatan penilaian modal atau kekayaan seorang calon debitur yang telah ditetapkan PT. Mandala Multifinance Tbk, Cabang Martapura, maka terdapat beberapa ketentuan penilaian modal atau kekayaan seorang calon debitur dengan menghitung financial yang dimiliki, barang-barang bergerak atau tidak bergerak sebagai ukuran kekayaan yang menentukan seberapa tahan financial seorang calon debitur. Dengan metode ketahanan financial seorang calon debitur pihak PT. Mandala Multifinance Tbk, Cabang Martapura dapat memperhitungkan seberapa tahan financial seorang calon debitur dengan penilaian ini pihak PT. Mandala Multifinance Tbk, Cabang Martapura dapat memperhitungkan seberapa aman kredit yang di salurkannya karena ketahan financial seorang calon debitur dapat ikut menentukan kembalinya kredit yang dipinjamkan PT. Mandala Multifinance Tbk, Cabang Martapura secara teratur sesuai dengan perjanjian kedua belah pihak.

Berdasarkan hasil observasi dan wawancara yang dilakukan peniliti, maka peneliti menganalisis bahwa pelaksanaan analisis pemberian kredit yang sesuai dengan ketentuan yang ada pada PT. Mandala Multifinance Tbk, Cabang Martapura belum berjalan baaik karena dalam penilaian modal dan kekayaan perlunya meminta bukti seperti pembayaran PBB untuk kepemilikan rumah sendiri agar dapat bisa dilihat dari bukti pembayaran PBB berjalan dengan lancar atau tidak dan perlu juga menghitung aset-aset yang dimiliki oleh calon nasabah agar bisa memperhitungkan kesanggupan calon nasabah dalam melakukan pembayaran kredit yang nanti akan diberikan oleh pihak kreditur.

\section{Collateral (Jaminan)}

Collateral merupakan tahapan dimana pihak kreditur menilai barang jaminan yang diserahkan oleh debitur 
sebagai jaminan atas kredit yang diterimanya. Manfaat dari collateral ini adalah sebagai pengaman apabila kredit yang disalurkan pihak kreditur kepada calon debitur mengalami masalah dalam pembayaran maupun dalam penyelesaian kreditnya. Tetapi collateral bukanlah alat pengaman yang paling efisien dalam menangani apabila terjadinya kreditr bermasalah. Hal ini dilakukan oleh pihak kreditur untuk memperlancar itu sendiri.

Penggunaan agunan ini dapat mengurangi risiko dari pinjaman yang ditentukan sejak pinjaman itu diberikan atas sebuah aset tanpa mengurangi tuntutan peminjam. Bpkb yang sekaligus menjadi jaminan dalam kredit, melalui tahap analisis yang dilakukan analis khusus yang dibentuk oleh PT. Mandala Multifinance Tbk, Cabang Martapura,dimana para analis mempelajari nilai jual harga sepeda motor untuk menentukan nilai kredit yang diberikan. Analisis tersebut wajib dilaksanakan untuk mengantisipasi terjadinya risiko atau permasalahan kredit, karena tidak jarang dalam pemberian fasilitas kredit terjadi kredit macet, baik yang disengaja atau tidak sengaja oleh calon debitur.

Adapun indikator yang dapat digunakan PT. Mandala Multifinance Tbk, Cabang Martapura dalam menilai jaminan yang diserahkan oleh debitur adalah sebagai berikut :

Rendahnya nilai jaminan dapat berpengaruh terhadap analisis pemberian kredit.

Kegiatan penilaian nilai agunan jaminan BPKB dan sepeda motor yang dimiliki calon debitur merupakan tahap analisis dimana menilai barang-barang jaminan dari calon debitur sebagai jaminan atas kredit yang diterimanya. Penilaian jaminan BPKB dan sepeda motor calon debitur ini bertujuan sebagai benteng terakhir apabila terjadi kredit bermasalah karena dengan menilai barang-barang jaminan yang dimiliki calon debitur pihak kreditur dapat mengantisipasi dengan menjual menarik dan menahan jaminan calon debitur tersebut untuk menutupi kerugian apabila terjadi.
Berdasarkan hasil observasi yang telah dilakukan oleh peneliti, rendahnya nilai jaminan dapat berpengaruh terhadap analisis pemberian kredit, kegiatan penilaian nilai jaminan BPKB dan sepeda motor yang dimiliki calon debitur yang dilaksanakan dan disesuaikan dengan prosedur yang telah ditetapkan oleh PT. Mandala Multifinance Tbk, Cabang Martapura, dimana dengan fungsi penilaian jaminan calon debitur ini PT. Mandala Multifinance Tbk, Cabang Martapura telah mampu menilai jaminan dari calon debitur yang mengajukan kreditnya.

Berdasarkan hasil wawancara dengan analisis kredit PT. Mandala Multifinance Tbk, Cabang Martapura diperoleh informasi bahwa untuk dapat melaksanakan kegiatan penilaian nilai jaminan bahwa untuk dapat melaksanakan kegiatan penilaian nilai agunan jaminan BPKB dan sepeda motor yang dimiliki calon debitur yang telah ditetapkan PT. Mandala Multifinance Tbk, Cabang Martapura maka terdapat beberapa ketentuan penilaian jaminan yang dimiliki calon debitur dengan menilai jaminan atas BPKB dan sepeda motor yang maasih layak dan dapat diperjual belikan yang tahun kendaranya diatas tahun 2009. Dengan metode jaminan ini maka pihak PT. Mandala Multifinance Cabang Martapura dapat memperhitungkan jaminan ini maka pihak PT. Mandala Multifinance Tbk, Cabang Martapura dapat memperhitungkan seberapa besar langkah antisipasi pertahanan kredit yang disalurkannya karena jaminan adalah hal yang mutlak ada dalam setiap pemberian kredit yang dipinjamkan PT. Mandala Multifinance Tbk, Cabang Martapura secara teratur sesuai dengan perjanjian yang telah disepakati.

Nilai jaminan yang dimiliki oleh debitur dapat mempengaruhi analisis kredit.

Jaminan yang cukup nilainya dan mudah diikat merupakan faktor penentu bagi kreditur untuk memberikan kepercayaan tentang debiturnya, nilai jaminan ini dapat berupa menilai jaminan nama baik calon debitur atau menilai kualitas tempat dimana calon debitur 
bekerja sebagai jaminan atas kelancaran kredit yang diajukan kepada kreditur. Penilaian jaminan calon debitur ini bertujuan sebagai benteng apabila terjadi kredit bermasalah karena dengan menilai nama baik calon debitur apakah melaksanakan perjanjian kreditnya dengan baik atau tidak.

Berdasarkan hasil observasi yang telah dilakukan oleh peniliti, kegiatan penilaian jaminan yang dimiliki oleh debitur dapat mempengaruhi dalam analisis pemberian kredit dan disesuaikan dengan prosedur yang telah ditetapkan oleh PT. Mandala Multifinance Tbk, Cabang Martapura, dimana dengan fungsi penilaian jaminan calon debitur ini PT. Mandala Multifinance Tbk, Cabang Martapura telah mampu menilai jaminan dari calon debitur yang mengajukan kreditnya.

Berdasarkan hasil wawancara dengan analis kredit untuk dapat melaksanakan kegiatan penilaian jaminan yang dimiliki calon debitur yang telah ditetapkan PT. Mandala Multifinance Tbk, Cabang Martapura maka terdapat beberapa ketentuan penilaian jaminan BPKB dan sepeda motor yang dimiliki calon debitur yaitu menilai jaminan dalam menganalisa dan menilai seberapa mendukung calon debitur. Dengan penilaian metode penilaian jaminan maka pihak PT. Mandala Multifinance Tbk, Cabang Martapura dapat memperhitungkan seberapa besar langkah antisipasi pertahanan kredit yang disalurkannya karena jaminan adalah hal yang juga mendukung dalam setiap pemberian kredit yang dilakukan PT. Mandala Multifinance Tbk, Cabang Martapura secara teratur sesuai dengan perjanjian kedua belah pihak.

Berdasarkan hasil observasi dan wawancara yang dilakukan peneliti, maka peneliti mmenganalisis bahwa pelaksanaan analisis pemberian kredit yang sesuai dengan ketentuan yang ada pada PT. Mandala Multifinance Tbk, Cabang Martapura belum berjalan dengan baik karena masih ada terdapat masalah dimana jaminan yang diajukan bukan milik calon nasabah.

\section{Condition Of Economic (Kondisi Ekonomi)}

Condition of economic mmerupakan tahapan terakhir dari analisis kredit yang menilai situasi dan kondisi politik, sosial, ekonomi, budaya dan lain-lain yang mempengaruhi keadaan perekonomian pada suatu maupun kurun waktu tertentu yang mungkin mempengaruhi pelunasan kredit calon debitur kepada kreditur. PT. Mandala Multifinance Tbk, Cabang Martapura menilai situasi-situasi yang akan terjadi dimasa yang akan datang karena tanpa bisa dihindari penilaian pemberian kredit akan sangat dipengaruhi oleh situasi politik sosial dan ekonomi negara yang akan selalu berubah sebagai upaya menghindari terjadinya kredit bermasalah.

Kondisi ekonomi, merupakan situasi pada waktu dan jangka waktu tertentu ketika kredit diberikan oleh kreditur kepada debiturnya. Adapun aspek yang menjadi dasar penentuan kondisi ekonomi adalah sebagai berikut :

Tingkat kejenuhan bidang usaha debitur berpengaruh terhadap pemberian kredit

Penilaian bidang usaha merupakan tehap dimana kreditur menilai situasi dan kondisi usaha calon debitur. Sebab dalam pemberian kredit harus memperhitungkan situasi dan kondisi usaha dari calon debitur yang akan mempengaruhi kelancaran pembayaran kredit calon debitur dimana dimasa yang akan datang. Penilaian kondisi usaha diantaranya menilai kebijakan-kebijakan pemerintah dalam bidang usaha, apakah usaha yang dijalankan debitur sejalan dengan kebijakan perusahaan. Untuk hal ini penilaian kondisi usaha oleh pihak kreditur masih kurang dan perlu dicari jalan keluarnya agar masalah tersebut dapat menemui titik terang.

Berdasarkan hasil observasi yang telah dilakukan oleh peniliti, kegiatan penilaian kondisi usaha debitur serta tingkat kejenuhan terhadap kegiatan usahanya yang dilaksanakan dan disesuaikan dengan prosedur yang telah ditetapkan oleh PT. Mandala Multifinance Tbk, Cabang Martapura, dimana dengan 
fungsi penilaian kondisi usaha calon debitur, PT. Mandala Multifinance Tbk, Cabang Martapura telah mampu menilai kondisi usahaa yang akan berpengaruh terhadap pelunasan kredit yang diajukan calon debitur.

Berdasarkan hasil wawancara dengan analisis kredit pinjaman PT. Mandala Multifinance Tbk, Cabang Martapura diperoleh informasi bahwa untuk dapat melaksanakan kegiatan penilaian kegiatan usaha telah ditetapkan beberapa ketentuan penilaian kepada calon debitur dengan adanya wawancara secara langsung dan menilai perusahaan tempat calon debitur bekerja, apakah sangat rentan dengan perubahan kondisi usaha atau tidak ?. Apabila peerusahaan tempat calon debitur bekerja rentang dengan perubahan kondisi usaha pada saat ini maka pengajuan kredit tersebut tidak dilanjutkan karena kondisi usaha tersebut dapat berubah dengan sangat cepat dan cukup sulit untuk diprediksi oleh analisis kredit secara mendalam. Dengan metode wawancara langsung dan menilai seberapa rentan perusahaan tempat calon debitur bekerja maka para analis kredit dapat menilai secara langsung bagaimana kondisi usaha calon debitur berpengaruh terhadap pengembalian kreditnya kepada PT. Mandala Multifinance Tbk, Cabang Martapura.

Banyaknya usaha sejenis yang dijalankan oleh calon debitur

berpengaruh terhadap pemberian kredit.

Penilaian terhadap banyaknya usaha sejenis yang dijalankan oleh debitur merupakan tahapan dimana pihak kreditur menilai situasi dan kondisi ekonomi pada saat dilakukannya analis kredit yang menyangkut jumlah usaha atau perusaahaan yang sejenis karena hal ini akan sangat ditentukan dengan pertumbuhan kondisi ekonomi calon debitur. Pertumbuhan ekonomi calon debitur akan terlihat meningkat dengan adanya peningkatan permintaan paasar bagi usaha yang dijalankan calon debitur yang diiringi dengan peningkatan penghasilan dari debitur. Hal ini menentukan tingkat pengembalian kredit calon debitur kepada piihak kreditur.

Berdasarkan dari hasil observasi data yang ada, maka peneliti menganalisis bahwa pelaksanaan analisis pemberian kredit yang sesuai dengan ketentuan yang ada pada PT. Mandala Multifinance Tbk, Cabang Martapura belum berjalan dengan baik dikarenakan belum dapat diperhatikan dengan begitu baik dalam memprediksi masalah ekonomi yang akan terjadi pada kemudian hari dan melakukan antisipasi yang perlu dilakukan Dalam hal meminimalisir kredit macet, PT. Mandala Multifinance Tbk, Cabang Martapura menerapkan analisis prinsip 5C, yaitu dengan melihat character (karakter), capacity (kemampuan), capital (modal), collateral (jaminan) dan condition of economy (kondisi ekonomi). PT. Mandala Multifinance Tbk, Cabang Martapura juga menerapkan prinsip 5C sesuai dengan persyaratan yang telah ditetapkan. Adapun penerapan prinsip 5C ini dilakukan oleh pihak PT. Mandala Multifinance Tbk, Cabang Martapura pada saat nasabah ingin mengajukan kredit, yaitu sebelum diajukan berkas persyaratan kredit dan setelah pengajuan berkas. Sebelum pengajuan berkas, analisa dilakukan secara wawacara kepada calon nasabah. Selanjutnya, untuk dapat mencegah terjadinya kredit macet.

\section{Kesimpulan}

Berdasarkan hasil penelitian dan wawancara yang telah peneliti lakukan terhadap pihak PT. Mandala Multifinance Tbk, Cabang Martapura dapat peneliti simpulkan :

setelah pengajuan berkas kredit dilakukan analisis prinsip 5C kembali, yaitu dengan observasi data dari berkas yang diberikan, wawancara dan observasi lapangan. Begitupu ketika kredit sudah diberikan pihak PT. Mandala Multifinance Tbk, Cabang Martapura tetap dilakukan upaya penganalisaan agar dapat terus meminimalisir risiko kredit macet.

Adapun Kendala dan Kekurangan yang dihadapi oleh PT. Mandala Multifinance Tbk, Cabang Martapura terletak pada prinsip 5C yaitu : dalam penilaian karakter calon debitur belum 
adanya BI Checking untuk menjadi bahan pertimbangan dalam pemberian kredit terhadap calon debitur.

\section{Daftar Pustaka}

Aman ,Tje' dan Mgs ,Edy Putra,2014, Kredit Perbankan SuatuTinjauan Yuridis, Yogyakarta : Liberty.

Djumhana ,Muhammad,2013, Hukum Perbankan Di Indonesia, Bandung : Citra Aditya Bakti.

Ikatan ,Akuntansi Indonesia, 2012, Pernyataan Standar Akuntansi Keuangan, Salemba Empat.

Ikatan ,Bankir Indonesia, 2014, Memahami Bisnis Bank Syariah, Jakarta : PT. Gramedia Pustaka Utama.

Imam Syakir, Soedarjanto, 2013, Dasar Dasar Moneter dan Perbankan, Surabaya : Bagian Dua.

Ismail, 2013, Manajemen Perbankan, Jakarta : Prenadamedia, Hal : 93 - 94.

,2013, Manajemen Perbankan, Jakarta : Prenadamedia, Hal : 125 - 127.

,2011, Perbankan Syariah, Jakarta : Kencana, Hal :120-125

Jusuf ,Jopie, Analisis Kredit Untuk Account Officer, Jakarta

Kasmir, 2011, Bank dan Lembaga Keuangan Lainnya. Jakarta : PT. Raja

Grafindo Persada, Hal : 268 - 269. 2010, Dasar-Dasar Perbankan. Jakarta : PT. Raja Grafindo Persada,

107.

,2014, Manajemen Perbankan Edisi Revisi. Jakarta : Rajawali.

Kuncoro, Mudjrad, 2012, Manajemen Perbankan : Teori dan Aplikasi, BPFE

Yogyakarta, Hal : 10.

Putra ,Edie, Kredit Perbankan, Yogyakarta : Liberty.

Tantri ,Francis,Abdulllah dan Thamrin, 2012, Bank dan Lembaga Keuangan, Jakarta : PT. Grafindo Persada. Trisadini, Wanti dan Shomad, Abdul, 2012, Transaksi Bank Syariah, Jakarta :

PT. Bumi Aksara. 